\title{
Tissue culture regeneration of three Nigerian cultivars of tomatoes
}

\author{
Ajenifujah-Solebo S. O. A. ${ }^{1 \star}$, Isu N. A. ${ }^{2}$, Olorode $0 .{ }^{2}$, Ingelbrecht I. ${ }^{3,5}$ and Abiade O. $0 .{ }^{4}$ \\ ${ }^{1}$ National Biotechnology Development Agency, Abuja, Nigeria. \\ ${ }^{2}$ Biological Sciences Department, University of Abuja, Abuja, Nigeria. \\ ${ }^{3}$ Department of Plant Biotechnology and Genetics, Gent University, Belgium. \\ ${ }^{4}$ Sheda Science and Technology Complex, Sheda, Abuja, Nigeria. \\ ${ }^{5}$ International Institute of Tropical Agriculture, Ibadan, Nigeria
}

Accepted 18 September, 2012

\begin{abstract}
The in-vitro response of three Nigerian cultivars of tomato - Ibadan local (IbL), Ife and JM94/46 (JM) were tested using cotyledons as explants for direct shoot regeneration. The cultivars showed variable responses in the two media used. In the medium consisting of an initial culture on pre-culture medium made up of Murashige and Skoog (MS) with $1.0 \mathrm{mg} \mathrm{L}^{-1}$ naphthaleneacetic acid (NAA) and $1.0 \mathrm{mg} \mathrm{L}^{-1} 6-$ benzylaminopurine (BAP) and subsequent culture on shoot regeneration medium consisting of MS with $0.1 \mathrm{mg} \mathrm{L}^{-1}$ thiamine, $0.5 \mathrm{mg} \mathrm{L}^{-1}$ indoleacetic acid (IAA) and $0.5 \mathrm{mg} \mathrm{L}^{-1}$ zeatin. Results showed that $15.65 \%$ of the cultured explants of IbL cultivar produced shoots, while Ife and JM cultivars did not produce any shoots. In the second medium consisting of MS with $0.1 \mathrm{mg} \mathrm{L}^{-1}$ IAA and $1.0 \mathrm{mg} \mathrm{L}^{-1}$ zeatin, $64-97 \%$ of the cultured cotyledon explants from the three cultivars produced shoots. Rooting medium was MS with 0.1 $\mathrm{ml} \mathrm{L}^{-1}$ NAA. Statistical analysis of regeneration data using Student Neuman Keul's (SNK) mean values for cultivar-medium interaction showed that Ife and JM94/46 were not significantly different $(P>0.05)$ for shooting explants and number of shoots. However, both were significantly different from $\mathrm{IbL} P<0.05$ for shooting explants and number of shoots produced. The least significant difference among the cultivars for shooting explants and number of shoots on the shoot regeneration medium was 0.0005 and 0.001 , respectively. SNK mean values for cultivar-media interaction for shooting explants and number of shoots produced were not significantly different $(P>0.05)$ among the three cultivars.
\end{abstract}

Key words: Nigeria, tomato, tissue culture, regeneration.

\section{INTRODUCTION}

Tomato (Solanum lycopersicum L.) is a fleshy vegetable used all over the world. It belongs to the family Solanaceae, and is the world's most widely cultivated vegetable (Villarael, 1980) with an estimated global production of over 120 million metric tons (F.A.O. 2007). Tomato fruits are a significant source of nutrition for substantial portions of the world's human population because this vegetable crop is widely cultivated and consumed extensively as both fresh vegetable and concentrated processed products (Hamner and Maynard,

*Corresponding author. E-mail: adetoyin73@yahoo.com. Tel: +2348098244979.
1942; Beecher, 1998). In tropical Africa, the area used for tomato cultivation is about 300,000 ha, with an estimated annual production of 2.3 million tonnes. Nigeria is the largest producer, accounting for 126,000 ha and an annual production of 879,000 tonnes (Van der Vossen et al., 2004). In developing countries like Nigeria, efficient storage, packaging, transport and handling techniques are practically non-existent with perishable crops (Babalola et al., 2010), resulting in considerable loss of produce. Therefore improvements such as longer shelflife, resistance to biotic and abiotic stresses, nutrient enhancement, higher soluble solids, etc are desirable in the local cultivars of tomato. However, the introduction of genes that confer these qualities to commercial cultivars by conventional breeding techniques often encounters 
serious difficulties due to high incompatibility barriers to hybridization (Kaul, 1991). To overcome these problems more recent approaches of gene manipulation might be required.

The establishment of an efficient tissue culture protocol is an essential pre-requisite for harnessing the advantage of cell and tissue culture for genetic improvement. Meanwhile, the lack of a good regeneration protocol limits the efficiency or percentage of the transformants obtainable. There is, however, paucity of documented work on the in-vitro regeneration of Nigerian cultivars of tomato; such work would provide the background work for the application of genetic engineering in solving these problems. The development of protocols for in-vitro selection can provide new advances for the production of stress tolerant cultivars (Bhatia et al., 2004). There is therefore an urgent need to domesticate these technologies for the improvement of Nigerian indigenous cultivars of tomatoes. Efficient plantlet regeneration in tomato was reported from the leaf (Behki and Lesley, 1976; Kartha et al., 1976; Padmanabhan et al., 1974). The success in tomato regeneration response has been found to depend largely on genotype, explant and plant growth regulators used in the culture medium (Praveen and Rama Swamy, 2011).

In vitro regeneration of cultivated tomato ( $S$. lycopersicum) has been a subject of research because of the commercial value of the crop and its potential of amenability to further improvement through genetic engineering strategy (Evans, 1989). The choice of cultivars used in this study is based on agronomic studies carried out at the National Institute for Horticultural Research and Training (NIHORT). Ibadan local and Ife cultivars are farmer preferred varieties in the southwestern part of Nigeria, which are reported to be resistant to certain diseases and relatively high yielding (Badra et al., 1984; Anno-Nyako and Ladunni, 1984). ICS-Nigeria (Anonymous, 2000) also reported Ife cultivar to be high yielding with fruits and is a determinate bushy plant; and that other local cultivars are fairly resistant to virus, have round and irregularly shaped fruits that are soft and prone to cracking.

\section{MATERIALS AND METHODS}

\section{In-vitro regeneration of the tomato cultivars}

In-vitro regeneration study of three local cultivars of tomato by shoot organogenesis was carried out in two shoot regeneration media $\left(\mathrm{SRM}_{1}\right.$ and $\left.\mathrm{SRM}_{2}\right)$ using complete randomized design (CRD) in replicated experiments. The seeds of three local cultivars of tomatoes namely Ibadan local, Ife and JM94/46, were obtained from the National Institute for Horticultural Research and Training (NIHORT), Ibadan, and tested for germinability. Different combinations of surface seed sterilization treatments with varying concentration and duration of application of sodium hypochlorite $(\mathrm{NaOCl})$ and $70 \%$ ethanol were carried out in triplicates on the tomato seeds. Optimum sterilization protocol for seeds of the tomato cultivars was treatment with $\mathrm{NaOCl}(3.5 \%)$ for 20 min without an ethanol treatment. A drop of Tween 20 was added and the seeds were rinsed with sterile distilled water at least three times.

\section{Media and sterilization}

Murashige and Skoog (MS) medium (Murashige and Skoog, 1962) was prepared and adjusted to $\mathrm{pH} 5.8$, filled into culture bottles and sterilized by autoclaving at $121^{\circ} \mathrm{C}$ at $15 \mathrm{psi}$ for $15 \mathrm{~min}$. The efficiency of sterilization was ascertained using Bowie-Dick auto clave tape which changed from blue to white. About $50-100 \mathrm{ml}$ of the medium was dispensed into each previously sterilized culture jar while still hot under the laminar flow hood and allowed to cool. The seeds were inoculated onto sterile, cooled and solidified germination medium (GM). The various media used are:

Germination medium $(\mathrm{GM})=\mathrm{MS}+30 \mathrm{~g} \mathrm{~L}^{-1}$ sucrose $+8 \mathrm{~g} \mathrm{~L}^{-1}$ agar gel (Cortina et al., 2004)

$\mathrm{SRM}_{1}$ consisted of an initial culture in preculture medium for two days

Preculture medium $(\mathrm{PM})=\mathrm{MS}+30 \mathrm{~g} \mathrm{~L}^{-1}$ sucrose $+8 \mathrm{~g} \mathrm{~L}^{-1}$ agar gel $+1 \mathrm{mg} \mathrm{L}^{-1}$ naphthaleneacetic acid (NAA) + $1 \mathrm{mg} \mathrm{L}^{-1} 6$ benzylaminopurine (BAP) (Cortina et al., 2004)

$\mathrm{SRM}_{1}=\mathrm{MS}+30 \mathrm{~g} \mathrm{~L}^{-1}$ sucrose $+8 \mathrm{~g} \mathrm{~L}^{-1}$ agar gel $+0.1 \mathrm{mg} \mathrm{L}^{-1}$ thiamine $+0.5 \mathrm{mg} \mathrm{L}^{-1}$ indoleacetic acid (IAA) $+0.5 \mathrm{mg} \mathrm{L}^{-1}$ zeatin (Cortina et al., 2004)

$\mathrm{SRM}_{2}=\mathrm{MS}+0.1 \mathrm{mg} \mathrm{L}^{-1} \mathrm{IAA}+1 \mathrm{mg} \mathrm{L}^{-1}$ zeatin $+8 \mathrm{~g} \mathrm{~L}-1$ agar gel (Tingting et al., 2005)

Rooting medium $(\mathrm{RM})=\mathrm{MS}+15 \mathrm{~g} \mathrm{~L}^{-1}$ sucrose $+8 \mathrm{~g} \mathrm{~L}^{-1}$ agar gel + $0.1 \mathrm{ml} \mathrm{L}^{-1} \mathrm{NAA}$ (Davis et al., 1994)

\section{In-vitro tomato seed germination}

In-vitro tomato seedlings were produced according to the methods described by Cortina et al. (2004). Surface-sterilized tomato seeds were inoculated on germination medium (GM). Each culture jar containing GM was inoculated with ten sterilized seeds and were placed in the dark at $25 \pm 2^{\circ} \mathrm{C}$ for 3 - 5 days to germinate and then brought to light for a $16 \mathrm{~h}$ photoperiod with light intensity of 1500 lux for $7-10$ days at the same temperature.

\section{Regeneration through direct shoot organogenesis}

Cotyledon explants $\left(5 \times 5 \mathrm{~mm}^{2}\right)$ from $10-13$ days old in-vitro seedlings of tomato seedlings were cut off, the tips removed and sectioned transversely with a sterile scalpel. Fifteen pieces of cotyledon explants from each cultivar were cultured per Petri dish in triplicates. Shoot regeneration was established in $\mathrm{SRM}_{1}$, which consisted of an initial culture in preculture medium (PM) for 2 days before being transferred to $\mathrm{SRM}_{1}$ (Cortina et al., 2004) and in $\mathrm{SRM}_{2}$ with the explant pieces placed upside down. After about 3 - 4 weeks in the shoot regeneration media, regenerated shoots were subcultured into modified rooting medium (RM) and after 10 days in $\mathrm{RM}$, rooted plants were transferred to the screen house for hardening.

\section{Seedling establishment}

According to methods described by Raj et al. (2005), rooted plants were transferred to hardening medium consisting of coconut fibre 
Table 1. Regeneration data in $\mathrm{SRM}_{1}$.

\begin{tabular}{lccccccccc}
\hline Cultivar & $\begin{array}{c}\text { No. of } \\
\text { explant }\end{array}$ & $\begin{array}{c}\text { Survived } \\
\text { explant }\end{array}$ & $\begin{array}{c}\% \\
\text { survival }\end{array}$ & $\begin{array}{c}\text { Mean survival } \\
\pm \text { S.E. }\end{array}$ & $\begin{array}{c}\text { Shoot } \\
\text { explant }\end{array}$ & $\begin{array}{c}\% \text { Shoot } \\
\text { explant }\end{array}$ & $\begin{array}{c}\text { Mean shoot } \\
\text { explant } \pm \text { S.E. }\end{array}$ & $\begin{array}{c}\text { No. } \\
\text { shoots }\end{array}$ & $\begin{array}{c}\text { Average shoot } \\
\text { /explant }\end{array}$ \\
\hline IbL & 45 & 37 & 82.22 & $0.822 \pm 0.06$ & 7 & 15.65 & $0.156 \pm 0.051$ & 15 & 2.14 \\
Ife & 45 & 39 & 86.67 & $0.867 \pm 0.05$ & 0 & 0 & 0 & 0 & 0 \\
JM & 45 & 33 & 73.33 & $0.733 \pm 0.07$ & 0 & 0 & 0 & 0 & 0 \\
\hline
\end{tabular}

Explant type: cotyledon.

Table 2. Regeneration data in $\mathrm{SRM}_{2}$.

\begin{tabular}{lccccccccc}
\hline Cultivar & $\begin{array}{c}\text { No. of } \\
\text { explant }\end{array}$ & $\begin{array}{c}\text { Survived } \\
\text { explant }\end{array}$ & $\begin{array}{c}\% \\
\text { survival }\end{array}$ & $\begin{array}{c}\text { Mean survival } \\
\pm \text { S.E. }\end{array}$ & $\begin{array}{c}\text { Shoot } \\
\text { explant }\end{array}$ & $\begin{array}{c}\% \text { Shoot } \\
\text { explant }\end{array}$ & $\begin{array}{c}\text { Mean shoot } \\
\text { explant } \pm \text { S.E. }\end{array}$ & $\begin{array}{c}\text { No. } \\
\text { shoots }\end{array}$ & $\begin{array}{c}\text { Average shoot } \\
\text { /explant }\end{array}$ \\
\hline IbL & 45 & 44 & 97.78 & $0.978 \pm 0.022$ & 44 & 97.78 & $0.978 \pm 0.022$ & 125 & 2.84 \\
Ife & 45 & 41 & 91.11 & $0.911 \pm 0.043$ & 37 & 82.22 & $0.822 \pm 0.058$ & 134 & 3.62 \\
JM & 45 & 36 & 80.0 & $0.8 \pm 0.060$ & 29 & 64.44 & $0.644 \pm 0.072$ & 97 & 3.35 \\
\hline
\end{tabular}

Explant type: cotyledon.

Table 3. SNK test for mean values in $\mathrm{SRM}_{1}-$ cultivar $^{\star}$ media.

\begin{tabular}{lccc}
\hline Cultivar & IbL & Ife & JM \\
\hline Survive & $0.822^{\mathrm{a}}$ & $0.867^{\mathrm{a}}$ & $0.733^{\mathrm{a}}$ \\
shoot explant & $0.156^{\mathrm{a}}$ & $0^{\mathrm{b}}$ & $0^{\mathrm{b}}$ \\
Shoots & $0.333^{\mathrm{a}}$ & $0^{\mathrm{b}}$ & $0^{\mathrm{b}}$ \\
\hline
\end{tabular}

Mean values with same letters on the same row are not significantly different at $\alpha=0.05$.

pellets (peat) that were soaked in water for about $3 \mathrm{~h}$ to loosen up and vermiculite was added to make the medium sturdy enough to keep the plants upright. The mixture was poured into polythene bags and the rooting plants from RM were transferred into the medium. They were kept in humidity chamber for 2 weeks before planting in soil, still under humidity chamber and gradually acclimatized in the screen house environment.

\section{Statistical analysis of regeneration data}

Pooled data from the regeneration experiments was subjected to analysis of variance (ANOVA) using the general linear model (GLM) procedure of statistical analysis software (SAS Institute, Cary, NC). Least significant difference (LSD) test was based on Student Neuman Keuls' (SNK) procedure after a significant F-test in the analysis of variance.

\section{RESULTS AND DISCUSSION}

\section{Sterilisation and in -vitro germination of tomato seeds}

Sterilization treatment with $2 \%$ hypochlorite for $10 \mathrm{~min}$, $70 \%$ ethanol for $1 \mathrm{~min}$ and $3.5 \%$ hypochlorite for $20 \mathrm{~min}$ without the ethanol treatment gave optimum sterilization of the explants. Cultivar JM germinated 3 days after planting (d.a.p.), while Ife and $\mathrm{IbL}$ germinated from 5 d.a.p.

\section{Direct shoot regeneration}

Only $15.65 \%$ of the cultured $\mathrm{lbL}$ cultivar explants produced shoots in $\mathrm{SRM}_{1}$ (Table 1) with average shoots per explant of 2.14. Ife and JM cultivars did not produce any shoots from the cotyledon explants in $\mathrm{SRM}_{1}$. However, all the cultivars survived in the media for the eight week period they were on $\mathrm{SRM}_{1}$ at $82.22,86.67$ and $73.33 \%$ for $\mathrm{IbL}$, Ife and JM cultivars respectively (Figure 1). In $\mathrm{SRM}_{2}, 64-97 \%$ of cultured explants produced shoots across the three cultivars (Table 2). The highest number of shooting explants was observed in IbL $(97.78 \%)$ and the highest average shoot per explant was recorded in cultivar Ife at 3.62. Higher percentage survival was also recorded in $\mathrm{SRM}_{2}$ for all cultivar types. Student-Newman-Keuls (SNK) mean values for cultivarmedium interaction in $\mathrm{SRM}_{1}$ (Table 3) showed there was no significant difference in the survival rate among the three cultivars $(P>0.05)$; while Ife and JM were not significantly different $(P>0.05)$ for shooting explants and number of shoots. They were both significantly different from IbL $\mathrm{P}<0.05$ for shooting explants and number of shoots produced. The least significant difference among the cultivars for survival, shooting explants and number of shoots on SRM was 0.268, 0.0005 and 0.001 respectively. Furthermore, the SNK values for cultivarmedium interaction in $\mathrm{SRM}_{2}$ (Table 4) showed there was no significant difference $(P>0.05)$ among the three cultivars for number of calli, shooting explants and number of shoots per explants. 
Table 4. SNK test for mean values in $\mathrm{SRM}_{2}$ cultivar*media.

\begin{tabular}{lccc}
\hline Cultivar & IbL & Ife & JM \\
\hline No calli & $0.833^{\mathrm{a}}$ & $0.811^{\mathrm{a}}$ & $0.878^{\mathrm{a}}$ \\
shoot calli & $0.644^{\mathrm{a}}$ & $0.644^{\mathrm{a}}$ & $0.711^{\mathrm{a}}$ \\
Shoots & $1.711^{\mathrm{a}}$ & $2.011^{\mathrm{a}}$ & $2.156^{\mathrm{a}}$ \\
\hline
\end{tabular}

Mean values with same letters on the same row are not significantly different at $\alpha=0.05$.
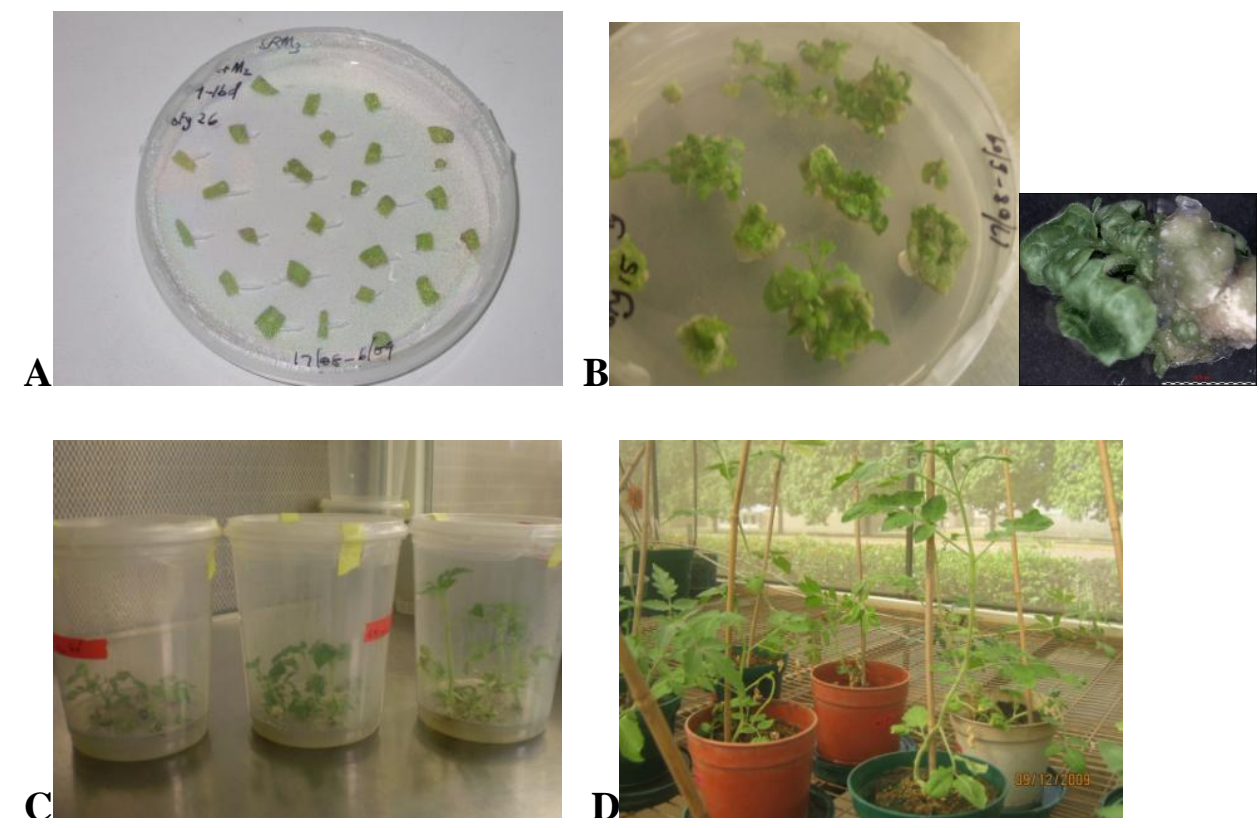

Figure 1. (A) Cotyledon explants - day 0; (B) cotyledon explants in SRM at 6 weeks (inset: close shot of shooting explants); (C) regenerated tomato seedlings in RM - 8 weeks; (D) rooted tissue culture tomato plants in top soil in screen house (4 months).

\section{Rooting and hardening of regenerated shoots}

Shoots were ready for rooting after 4 - 6 weeks in shoot regeneration media. The regenerated shoots were transferred to RM (Sun et al., 2006) without exogenous hormones. Regenerated shoots did not produce roots after three weeks in the RM. Mensuali-Sodi et al. (1995) also reported that tomato does not usually require any plant growth regulators (PGR) for rooting. The addition of $0.1 \mathrm{ml} \mathrm{L}^{-1}$ of NAA to the RM however resulted in the development of roots after 10 days in the modified RM. Davis et al. (1994) and Compton and Veilleux (1991) reported the use of NAA at concentrations of 0.1 and $0.02 \mathrm{mg} \mathrm{L}^{-1}$, respectively to induce rooting from tomato leaf and hypocotyl explants.

In tomato, adventitious shoot regeneration can be achieved either directly (Dwivedi et al., 1990) or indirectly through an intermediate callus phase (Behki and Lesley, 1980; Geetha et al., 1998). Bhatia (2003) reported that both callus and shoots may be produced together. The in-vitro morphogenic responses of cultured plant tissues are affected by the different components of the culture media, especially by concentration of growth hormones as well as genotype, explant type and age. $\mathrm{SRM}_{1}$ with 0.5 $\mathrm{mg} \mathrm{L}^{-1}$ zeatin did not support shoot induction in the cultivars/explants. BAP and IAA at the concentrations used in the PM did not also improve shoot regeneration in the cotyledon explants. However, in $\mathrm{SRM}_{2}$ with concentrations of $0.1 \mathrm{mg} \mathrm{L}^{-1} \mathrm{IAA}$ and $1.0 \mathrm{mg} \mathrm{L}^{-1}$ zeatin shoot regeneration of $64-97 \%$ of cultivated cotyledon explants was recorded across the three cultivars. Godishala et al. (2012) and Ting-ting et al. (2005) also reported that $1.0 \mathrm{mg} \mathrm{L}^{-1}$ zeatin enhanced adventitious shoot regeneration in tomatoes. In addition, Jozef et al. (2004) reported that the addition of growth regulators in media influenced the number of shoots regenerated from tomato cotyledons.

Although previous studies demonstrated that 8 to 10 day-old cotyledons of tomato were superior to other source of explants, including hypocotyls, stems and leaves for promoting shoot organogenesis of tomato (Pino et al., 2010; Hamza and Chupeau, 1993; Van 
Roekel et al., 1993; Ling et al., 1998), in these experiments 10 - 13 day-old cotyledons were used successfully as source of explants. Cortina et al. (2004) reported the effective use of 10 - 13 day-old cotyledons as source of explants. Godishala et al. (2012) also reported the successful use of $10-12$ day-old tomato cotyledon as explants for tomato regeneration. Moreover, Zhang et al. (2012) reported that the most ideal explant for tomato in-vitro regeneration is the cotyledon. Nogueira et al. (2001) also observed high regeneration frequency 92 or $85 \%$ on cotyledonary explants of genotype Santa Clara or its natural mutant Firme, respectively, which corroborates the results obtained for $\mathrm{IbL}$ and lfe in $\mathrm{SRM}_{2}$.

Based on the results of this study, $\mathrm{SRM}_{2}$ is better suited for the in-vitro regeneration of the local tomato cultivars than $\mathrm{SRM}_{1}$. This is probably due to the higher concentration of zeatin in $\mathrm{SRM}_{2}$. Zeatin has been reported to support shoot regeneration in in-vitro tomato cultures (Pino et al., 2010). The results of these experiments in the two different media confirm that invitro regeneration responses in tomatoes are dependent on composition of media, explant and cultivar type. Also 10 - 13 day-old cotyledon explants are suitable for in-vitro regeneration of the three local cultivars.

\section{ACKNOWLEDGEMENTS}

The authors acknowledge the funding support of the National Biotechnology Development Agency-Post Basic Science and Technology Education World Bank Project (NABDA STEP-B World Bank Project) and the use of facilities at the International Institute of Tropical Agriculture (IITA), Ibadan and Sheda Science and Technology Complex (SHESTCO), Sheda, Abuja, Nigeria.

\section{REFERENCES}

Anonymous (2000). Growing Tomatoes in Nigeria. Commercial crop production guide series. A publication of International Institute of Tropical Agriculture (IITA) supported by United States Agency for International development (USAID) Information and Communication Support for Agricultural growth in Nigeria (ICS-Nigeria). pp. 1-4.

Anno-Nyako F, Ladunni A (1984). Evaluation of tomato germplasm under field conditions for reaction to tomato virus disease. National Institute for Horticultural Research and Training (NIHORT) Annual Report pp. 23-24.

Babalola DA, Makinde YO, Omonona BT, Oyekanmi, MO (2010). Determinants of post harvest losses in tomato production: a case study of Imeko-Afon local government area of Ogun State. Acta SATECH 3(2):14-18.

Badra T, Denton O, Anyim O (1984). Tomato germplasm evaluation. National Institute for Horticultural Research and Training (NIHORT) Annual Report pp. 22-23.

Beecher GR (1998). Nutrient Content of tomatoes and tomato products. Proc. Soc. Exp. Biol. Med. 218(2):98-100.

Behki RM, Lesley SM (1976). In-vitro plant regeneration from leaf explants of Lycopersicum esculentum (tomato). Can. J. Bot. 54:24092414.

Behki RM, Lesley SM (1980). Shoot regeneration from leaf callus of
Lycopersicum esculentum. Zeitschrift Fur Pflanzenphysiologie 98:8387.

Bhatia P, Ashwath N, Senaratna T, Midmore D (2004). Tissue culture studies of tomato (Lycopersicum esculentum). Plant Cell Tiss. Org. Cult. 78:1-21

Bhatia P (2003). Optimization of physical, chemical and biological factors for in-vitro micropropagation through direct regeneration, axillary branching and somatic embryogenesis methods for the red coat variety of tomato (Lycopersicum esculentum Mill.). PhD thesis, Central Queensland University, Australia Compton ME, Veilleux RE (1991). Shoot, root and flower morphogenesis on tomato inflorescence explants. Plant Cell Tiss. Org. Cult. 24:223-231.

Cortina C, Culianez-Macia F (2004). Tomato transformation and transgenic plant production. Plant Cell Tiss. Org. Cult. 76:269-275.

Davis DG, Breiland KA, Frear DS, Secor GA (1994). Callus initiation and regeneration of tomato (Lycopersicum esculentum) cultivars with different sensitivities to metribuzin. Plant Growth Reg. Soc. Am. Q. 22:65-73.

Dwivedi K, Srivastava P, Verma HN, Chaturvedi HC (1990). Direct regeneration of shoots from leaf segments of tomato (Lycopersicum esculentum) cultured in-vitro and production of plants. Indian J. Exp. Biol. 28:32-35.

Evans DA (1989). Somaclonal variation - genetic basis and breeding applications. Trends Genet. 5:46-50.

FAO (2007) FAOStat, core production 2005 http://faostat.fao.org/site/340/default.aspx

Geetha N, Venkatachalan P, Reddy PS, Rajaseger G (1998). In-vitro plant regeneration from leaf callus cultures of tomato (Lycopersicum esculentum Mill.). Adv. Plant Sci. 11:253-257.

Godishala V, Kairamkonda M, Kagithoju S, Mangamoori L, Nanna RS (2012). Zeatin induced direct multiple shoots development and plant regeneration from cotyledon explants of cultivated tomato (Solanum lycopersicum L.). Aust. J. Crop Sci. 6(1).

Hamner KC, Maynard LA (1942). Factors influencing the nutritional value of the tomato. A review of literature, U.S. Dept. of Agric. Misc. publication p. 52.

Hamza S, Chupeau Y (1993). Re-evaluation of conditions for plant regeneration and Agrobacterium-mediated transformation from tomato (Lycopersicum esculentum Mill.). J. Exp. Bot. 44:1837-1845.

Jozef G, Zuzana L, Zuzana J (2004). Effect of growth regulators on shoot induction and plant regeneration in tomato (Lycopersicum esculentum Mill.). Biologia Bratislava 59(3):405-408.

Kartha KK, Gamborg OL, Shyluk JP, Constable F (1976). Morphogenic investigations on in vitro leaf culture of tomato (Lycopersicum esculentum Mill. cv. Starfire) and high frequency plant regeneration. Zeitschrift Fur Pflanzenphysiologie. 77:292-301.

Kaul M (1991). Reproductive biology of tomato. In: Kalloo G. (eds). Monographs on Theoretical and Applied Genetics 14, Genetic Improvement of Tomato (pp. 1-9). Springer-Verlag, Berlin, Heidelberg, New York.

Ling HQ, Kriseleit D, Ganal MW (1998). Effect of ticarcillin/potassium clavulanate on callus growth and shoot regeneration in Agrobacterium-mediated transformation of tomato (Lycopersicum esculentum Mill.). Plant Cell Rep. 17:843-847.

Mensuali-Sodi A, PanizzaM, Togoni F (1995). Endogenous ethylene requirement for adventitious root induction and growth in tomato cotyledons and lavandin microcuttings in-vitro. Plant Growth Reg. 17:205-212.

Murashige T, Skoog F (1962). A revised medium for rapid growth and bioassays with tobacco tissue cultures. Physiol. Plant. 15:473-497.

Nogueira FTS, Costa MG, Figueira ML, Otoni WC, Finger FL (2001). Invitro regeneration of "Santa Clara" tomato plantlets and its natural mutant "Firme". Sci. Agrotech. Lavras 25:36-71.

Padmanabhan V, Paddock EF, Sharp WR (1974). Plantlet formation from Lycopersicum esculentum leaf callus. Can. J. Bot. 52:14291432.

Pino LE, Lombardi-Crestana S, Azevedo MS, Scotton DC, Borgo L, Quecini V, Figueira A, Peres LEP (2010). The Rg1 allele as a valuable tool for genetic transformation of the tomato "Micro-Tom" model system. Plant methods 6:23.

Praveen M, Rama-Swamy N (2011) Effect of genotype, explant source and medium on in-vitro regeneration of tomato. Int. J. Gen. Mol. Biol. 
$3(3): 45-50$.

Raj S, Singh R, Pandey S, Singh B (2005). Agrobacterium-mediated transformation and regeneration of transgenic lines expressing tomato leaf curl virus coat protein gene for resistance against TLCV infection. Curr. Sci. 88(10):1674-1679.

Sun H, Uchii S, Watanabe S, Ezura H (2006). A highly efficient transformation protocol for Micro-Tom, a model cultivar for tomato functional genomics. Plant Cell Physiol. 47(3):426-431.

Tingting C, Zhou S, Sauve R, Bhatti S, Powell W (2005). In-vitro Regeneration of Lycopersicon esculentum for genetic transformation studies. SNA Res. Conf. 50:628-631.

Van der Vossen H, Nono-Womdim M (2004). Lycopersicum esculentum Mill. In: Grubben G.J.H. and Denton O.A.(Eds). Plant Resources of Tropical Africa 2. Vegetables. PROTA Foundation, Wageningen, Netherlands/Backhuys Publishers, Leiden, Netherlands/CTA, Wageningen, Netherlands. pp. 373-379.
Van-Roekel JSC, Damm B, Melchers LS, Hoekema A (1993). Factors influencing transformation frequency of tomato (Lycopersicum esculentum). Plant Cell Rep. 12:644-647

Villareal RL (1980). Tomatoes in the Tropics. Boulder, Colorado: Westview Press pp. 174.

Zhang W, Hou L, Zhao H, Li M (2012). Factors Affecting Regeneration of Tomato Cotyledons. Biosci. Methods pp. 3-4. 